\title{
A new species of Philosepedon Eaton, 1904 (Diptera, Psychodidae) from Brazil
}

\author{
Cínthia Chagas ${ }^{1}$, Freddy Bravo $^{2,3}$ \& José Albertino Rafael ${ }^{1}$ \\ ${ }^{1}$ Coordenação de Pesquisas em Entomologia, Instituto Nacional de Pesquisas da Amazônia - INPA, \\ CP 478, CEP 69011-970, Manaus, Amazonas, Brazil, \\ e-mail: cinthia_chagas@yahoo.com.br,jarafael@inpa.gov.br \\ ${ }^{2}$ Departamento de Ciências Biológicas, Universidade Estadual de Feira de Santana - UEFS, \\ Av. Universitária, s/n, 44031-460, Feira de Santana, Bahia, Brazil \\ ${ }^{3}$ Corresponding author: Freddy Bravo, e-mail: freddy11bravo@yahoo.com.br
}

CHAGAS, C., BRAVO, F. \& RAFAEL, J.A. A new species of Philosepedon Eaton, 1904 (Diptera, Psychodidae) from Brazil. Biota Neotrop., 9(2): http://www.biotaneotropica.org.br/v9n2/en/abstract?article+bn01409022009.

Abstract: Philosepedon vieirai Chagas, Bravo \& Rafael, n. sp. from Brazil is described and illustrated. Keywords: Diptera, Psychodidae, Philosepedon, new species, Brazil.

CHAGAS, C., BRAVO, F. \& RAFAEL, J.A. Uma espécie nova de Philosepedon Eaton (Diptera, Psychodidae) do Brasil. Biota Neotrop., 9(2): http://www.biotaneotropica.org.br/v9n2/pt/abstract?article+bn01409022009.

Resumo: Neste trabalho é descrita a espécie Philosepedon vieirai Chagas, Bravo \& Rafael, sp. nov. do Brasil. Palavras-chave: Diptera, Psychodidae, Philosepedon, espécie nova, Brasil. 


\section{Introduction}

Philosepedon Eaton s.1. is a worldwide genus with 91 known species, 29 of them from the Neotropical Region (Duckhouse 1973, 1974; Quate 1996, 1999; Wagner \& Masteller 1996; Collantes \& Martínez-Ortega 1999; Ibañez-Bernal \& Cáceres 2005; Bravo et al. 2006). From Brazil were described 4 species: Philosepedon plaumanni (Duckhouse, 1968), P. spathipenis (Duckhouse, 1968), P. oblongolum Bravo, Chagas \& Cordeiro, 2006 and P. uncinatum Bravo, Chagas \& Cordeiro, 2006 (Duckhouse 1973, Bravo et al. 2006). A new species of Philosepedon from Brazil is described here.

\section{Material and Methods}

Specimens of Philosepedon were treated with $10 \% \mathrm{KOH}$, dehydrated and mounted in Canada balsam. Morphological terminology follows that of McAlpine (1981). Terminology specific to Psychodidae follows Duckhouse (1990), Bravo (2006) and Curler $\&$ Moulton (2008). The type-specimens were deposited in the Coleção Entomológica Padre Jesus Santiago Moure do Departamento de Zoologia da Universidade Federal do Paraná, Curitiba, Paraná, Brazil (DZUP), Coleção de Invertebrados do Instituto Nacional de Pesquisas da Amazônia, Manaus, Amazonas, Brazil (INPA) and Coleção Entomológica Professor Johann Becker do Museu de Zoologia da Universidade Estadual de Feira de Santana, Feira de Santana, Feira de Santana, Bahia, Brazil (MZUEFS).

\section{Results}

1. Philosepedon vieirai Chagas, Bravo \& Rafael, sp. nov. (Figures 1-10)

BRAZIL, Paraná, Jundiaí do Sul, Faz.[enda] Monte Verde, Malaise trap, PROFAUPAR (Project "Levantamento da Fauna Entomológica no Estado do Paraná”) 2.3, 04.v.[19]87, without name of collector, holotype male (DZUP); 1 paratype male, Pará, Serra do Cachorro, (ponto) $14 \mathrm{CDC} / \mathrm{m}$ [ata] light trap, 21.iv.1998, Toby Vicente Barret, Raul Queiróz, Francisco Lima Santos col. (INPA); 1 paratype male, Bahia, Ituberá, Pacangê, 09.iv.2007-10.vi.2007, light trap , Alvim, E. \& Equipe Ecopol. (MZUEFS); 1 paratype male, Bahia, Santa Terezinha, Serra da Jibóia, 24.viii.2000, Bravo, F. col. (MZUEFS); 2 paratype males, Bahia, Sauípe, 14.xi.2004, Bravo, F. col. (MZUEFS); 1 paratype male, Bahia, Ituberá, 1.vii.2003, Bravo, F. col. (MZUEFS).

Etymology: The name vieirai is dedicated to Rodrigo Marques Vieira.

\section{Description}

Male: Eye bridge with 4 facet rows (Figure 1); eyes separated by 0.5-1.0 facet diameter (Figure 1); interocular suture straight, without spur (Figure 1). Palpus formula = 1.0:1.5:1.6:1.7 (Figure 5); first palpomere with short area with sensorial rods (Figure 5). Antenna with 13 flagellomeres; flagellomeres

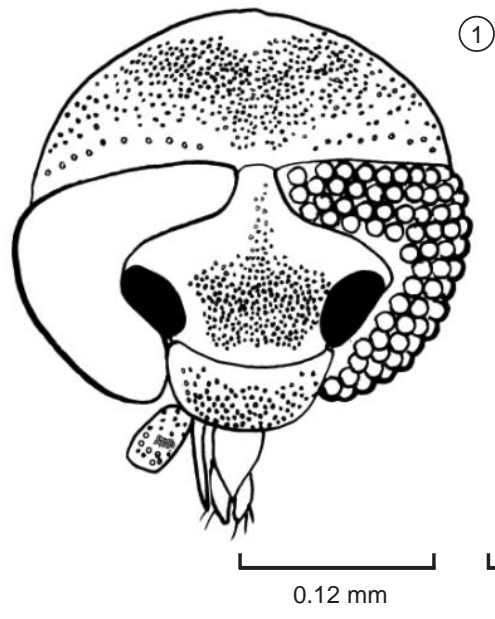

(1)

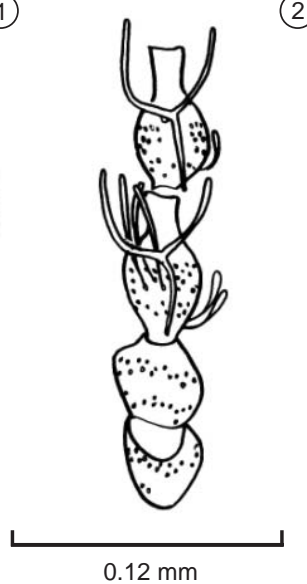

(2)

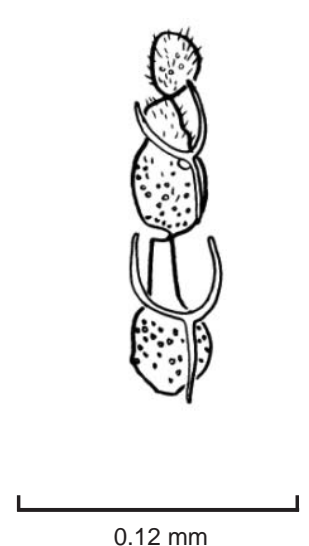

$0.12 \mathrm{~mm}$
(3)

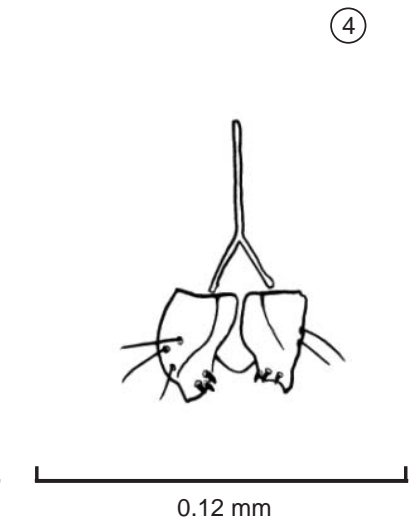

(9)

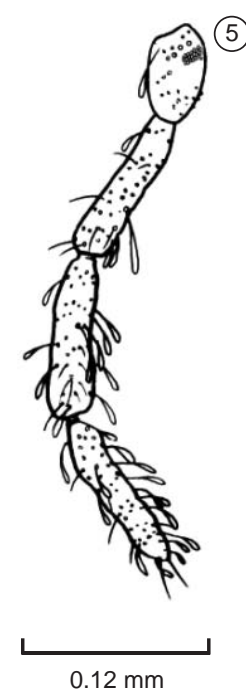

(10)
(6)

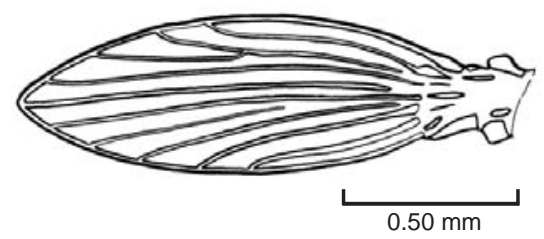

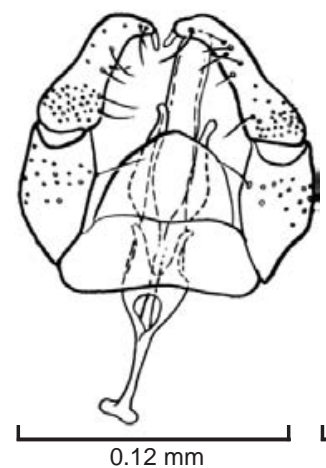

(7)
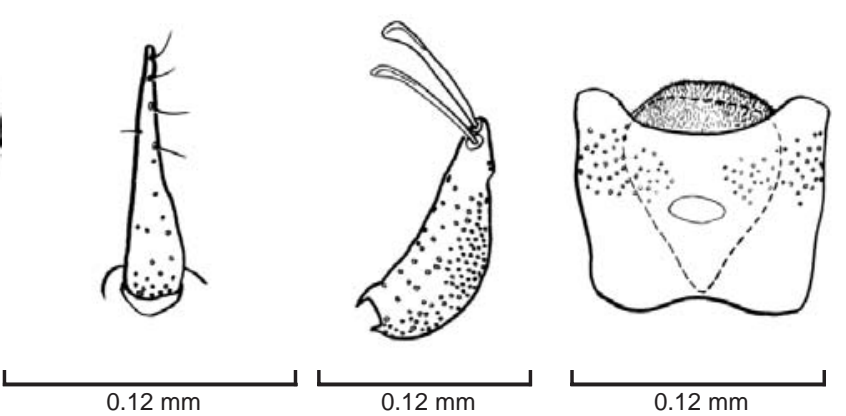

Figures 1-10. Philosepedon vieirai Chagas, Bravo \& Rafael, sp. nov. Male. 1. Head. 2. Antenna: scape, pedicel and basal flagellomeres. 3. Antenna, flagelomeres 10-13. 4. Labella. 5. Palpus. 6. Wing. 7. Male terminalia, dorsal. 8. Gonostyle, lateral view. 9. Cercus. 10. Male terminalia, ventral.

Figures 1-10. Philosepedon vieirai Chagas, Bravo \& Rafael, sp. nov. Macho. 1. Cabeça. 2. Antena: escapo, pedicelo e flagelômeros basais. 3. Antena, flagelômeros 10-13. 4 Labela. 5. Palpo maxilar. 6. Asa. 7. Terminália masculina, dorsal. 8. Gonóstilo, vista lateral. 9. Cerco. 10. Terminália masculina, ventral. 
1-10 nodiform (Figures 2, 3), flagellomeres 11, 12, and 13 reduced, 11 and 12 broadly fused, 13 separate (Figure 3 ); scape and pedicel sub-spherical, with approximately the same length (Figure 2); ascoids Y-shaped (Figures 2, 3). Labellum not flattened, with 3 apical short bristles (spines) and 3 long bristles (Figure 4). Thorax with additional proximal sclerite of the pteropleura, quadrangular. Wing (Figure 6) with reduced Sc, recognized by narrow strip of bristles; radial fork apical to medial fork; radial fork complete and medial incomplete; $\mathrm{CuA}$ wide in basal $2 / 3$ and thin in apical 1/3; costal cell, basal medial cell and cubital cell more sclerotized than the other areas of the wing membrane. Male terminalia (Figures 7-10): gonostyle with slightly hooked and pointed apex and opened to outer sides (Figure 8 ), almost $2 \times$ the length of the gonocoxite. Epandrium rectangular, the posterior margin depressed and with a central aperture (Figure 10). Hypandrium plate-like, trapezoidal, articulated to gonocoxites; post-hypandrial plate present. Tergite 10 with distal margin rounded, ending beyond the distal margin of sternite 10 (Figure 10); sternite 10 with distal margin straight (Figure 10). Cercus larger than the length of epandrium, with 2 apical tenacula with rounded tips (Figure 9). Parameres bladeshaped, 1/2 length of aedeagus (Figure 7). Aedeagus symmetrical, $2 \times$ the length of the aedeagal apodeme (Figure 7). Aedeagal apodeme as figured (Figure 7).

Female: Unknown.

Geographical records: Brazil: Pará State, Bahia State (Atlantic Rain Forest) and Paraná State.

\section{Comments}

Philosepedon vieirai sp. nov. was collected in the states of Pará, in the Brazilian Amazon, Bahia, in the northeastern of Brazil, and Paraná, in the southern of Brazil. These collections suggest that the new species posses a wide distribution in Brazil.

The new species has a cercus with two tenacula, characteristic also observed in seven neotropical species of the genus: Philosepedon helicis (Dyar, 1929), P. aliciae Ibáñez-Bernal \& Cáceres, 2005, P. oblongolum, P. uncinatum, P. tritaxis Quate, 1996, P. mauroae Wagner \& Masteller, 1996 and P. duacopis Quate, 1999 (Quate 1996, 1999; Wagner \& Masteller 1996; Ibáñez-Bernal \& Cáceres 2005; Bravo et al. 2006). The other twenty two species of Philosepedon possess a different number of tenacula (Duckhouse 1968; Botosaneanu \& Vaillant 1970; Quate 1996, 1999): 1) six tenacula - P. atopos Quate, 1996; 2) four tenacula - P. tetartos Quate, 1996; 3) three tenacula - P. bicalcaratus Quate, 1996, P. dimorphus Quate, 1996, P. pollicaris Quate, 1996, P. tripetalis Quate, 1996, P. tritenaculus Quate, 1996, P. deceptrix Quate, 1996 and P. majorinus Quate, 1996; 4) a single tenaculum - P. parifucus Quate, 1996, P. hamatus Quate, 1996, P. ensiger Quate, 1996, P. bicuspis Quate, 1996, P. amblyles Quate, 1999, P. pandiculatus Quate, 1996, P. longistylus Quate, 1996, P. retusus Quate, 1996, P. fumata (Knab, 1914), P. ancepitis Quate, 1996, P. cubana (Botosaneanu \& Vaillant, 1970), P. spathipenis and P. plaumanni.

Philosepedon vieirai sp. nov. differs from $P$. helicis and P. aliciae by the shape of the anterior arms of the ascoid that are foliaceous in the two last species and digitiform in the new species. It differs from P. oblongolum and P. uncinatum by the presence of 13 flagellomeres in the two last species, by the absence of the characteristic oval apical enlargement of R2 and M3 vein in the new species, and besides by their different terminalia. P. oblongolum has parameres almost as long as aedeagus and $P$. uncinatum has a different shape of hypandrium than the new species (see Figure 17 of Bravo, et al. 2006).

The new species differs from $P$. tritaxis by the gonocoxites articulated to the hypandrium, while in the last species the gonocoxites are contiguous (Quate, 1996: 49). P. tritaxis, P. mauroae and P. duacopis differ from the new species by the relative length of the parameres, that is shorter than aedeagus in the new species and with almost of the same length of aedeagus in the three other species (Quate, 1996: Fig. 18b; Wagner \& Masteller, 1996: Fig. 45; Quate, 1999: Fig. 8a).

\section{Acknowledgements}

The authors would like to thank to Dr. Augusto Loureiro Henriques from INPA and Dr. Luciane Marinoni from DZUP who loaned the specimens, to two anonymous reviewers for their help improving the work, and to CNPq for a grant received by the first author.

\section{References}

BOTOSANEANU, L. \& VAILLANT, F. 1970. Trois Diptères Psychodidae nouveaux de Cuba. Trav. Lab. Hydrobiol. 61:173-183.

BRAVO, F. 2006. The taxonomy of Neotropical Brunettiina (Diptera, Psychodidae, Psychodinae, Mormiini) with descriptions of ten new species from Brazil and comments on the generic classification of this subtribe. Zootaxa. 1134:1-28.

BRAVO, F., CHAGAS, C. \& CORDEIRO, D.P. 2006. Two new species of Philosepedon Eaton (Diptera: Psychodidae: Psychodinae) from the Atlantic Coastal Rain Forest of northeastern Brazil. Zootaxa. 1206:63-68.

COLLANTES, F. \& MARTÍNEZ-ORTEGA, E. 1999. Nuevas citas conocidas de Psychodinae (Diptera: Psychodidae) en Nicaragua. Rev. Nica. Ent. 48:17-27.

CURLER, G.R. \& MOULTON, J.K. 2008. A review of the Nearctic species of the genus Eurygarka Quate (Diptera: Psychodidae). Zootaxa. 1740:28-36.

DUCKHOUSE, D.A. 1968. Psychodidae (Diptera, Nematocera) collected by Mr. Plaumann in Southern Brazil. Proc. R. Entomol. Soc. Lond. Ser B Taxon. 37(3-7):29-40.

DUCKHOUSE, D.A. 1973. Family Psychodidae. In A catalogue of the Diptera of the Americas South of the United States (N. Papavero, ed.). Museu de Zoologia; Universidade de São Paulo, São Paulo, p. 1-29.

DUCKHOUSE, D.A. 1974. Redescription of the Neotropical Psychodidae (Diptera, Nematocera) described by Knab, Dyar and Coquillet. J. Ent. (B). 42(2):141-152.

DUCKHOUSE, D.A. 1990. The Australasian genera of Pericomoid Psychodidae (Diptera) and the status of related Enderlein genera in the Neotropics. Invertebr. Taxon. 3(6):721-746.

DYAR, H.G. 1929. American Psychodidae (Diptera) III. Proc. Ent. Soc. Wash. 31:63-64.

EATON, A.E. 1904. New genera of European Psychodidae. Entomol. Mon. Mag. 40:55-59.

IBÁÑEZ-BERNAL, S. \& CÁCERES, A.G. 2005. Philosepedon aliciae sp. nov. de Psychodinae del Peru (Diptera: Psychodidade). Folia Entomol. Mex. 44(suppl.):157-164.

KNAB, F. 1914. New moth-flies (Psychodidae) bred form Bromeliaceae and other plants. Proc. V. S. Nat. Mus. 46(2015): 103-106.

McALPINE, J.F. 1981. Morphology and terminology: adults. In Manual of Neartic Diptera (J.F. Mcalpine, B.V. Peterson, G.E. Shewell, H.J. Teskey, J.R. Vockeroth \& D.M. Wood, eds). Research Branch Agriculture Canada, Ottawa, p. 9-63.

QUATE, L.W. 1996. Preliminary taxonomy of Costa Rican Psychodidae (Diptera), exclusive of Phlebotominae. Rev. Biol. Trop. 44(suppl.):1-81.

QUATE, L.W. 1999. Taxonomy of neotropical Psychodidae (Diptera 3. Psychodines of Barro Colorado Island and San Blas, Panama. In Contributions to the knowledge of Diptera (J. F. Burger, ed). Mem. Entomol. Int. 14:409-441.

WAGNER, R. \& MASTELLER, E.C. 1996. New moth flies (Diptera: Psychodidae) and a key to species from Puerto Rico. Proc. Entomol. Soc. Wash. 98(3):450-464. 